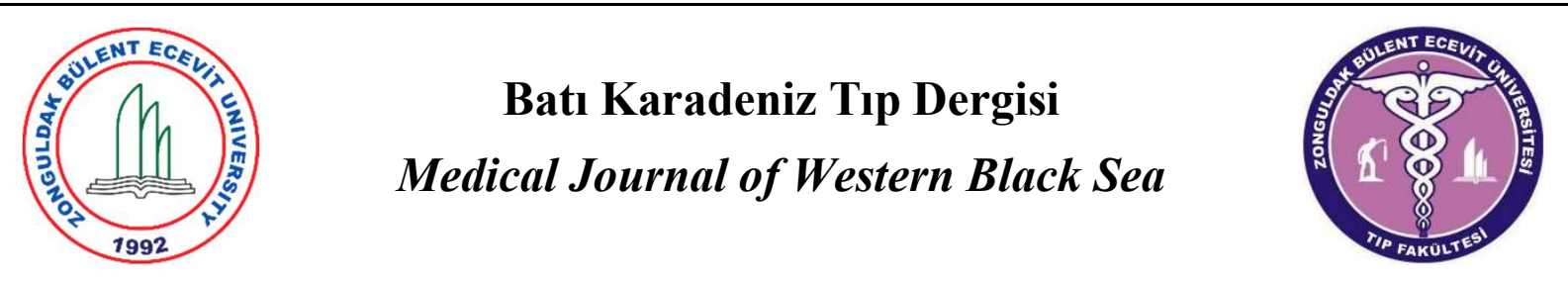

Araştırma Makalesi

Doi: 10.29058/mjwbs.2019.3.1

\title{
Tiroidektomi Sonrası Gelişen Geçici ve Kalıcı Hipokalsemi, Hipoparatiroidi ve Ses Kısıklığı Komplikasyonlarının Retrospektif İncelenmesi
}

Onur Amaç a , Ömer Batuhan Öztürk a , Nurşah Uslu a , Osman Alperen Balık ${ }^{\text {a }}$, Nurhayat Karaca a, Ömer Tarık Çok ${ }^{a}$, Mustafa Sinan Kuşçuoğlu ${ }^{\text {a }}$, Ali Uğur Emre ${ }^{\text {b }}$

${ }^{a}$ Zonguldak Bülent Ecevit Üniversitesi, Tıp Fakültesi Öğrencisi, Zonguldak, Türkiye.

${ }^{b}$ Zonguldak Bülent Ecevit Üniversitesi Tıp Fakültesi, Genel Cerrahi Anabilim Dalı, Zonguldak, Türkiye.

ORCID : Onur Amaç 000000033729 3225, Ömer Batuhan Öztürk 000000034951 0469, Nurşah Uslu 000000017615 3351, Osman Alperen Balık 000000030763 4965, Nurhayat Karaca 000000020858 2979, Ömer Tarık Çok 000000030552 7736, Mustafa Sinan Kuşçuoğlu 000000031891 4778, Ali Uğur Emre 0000000211360517

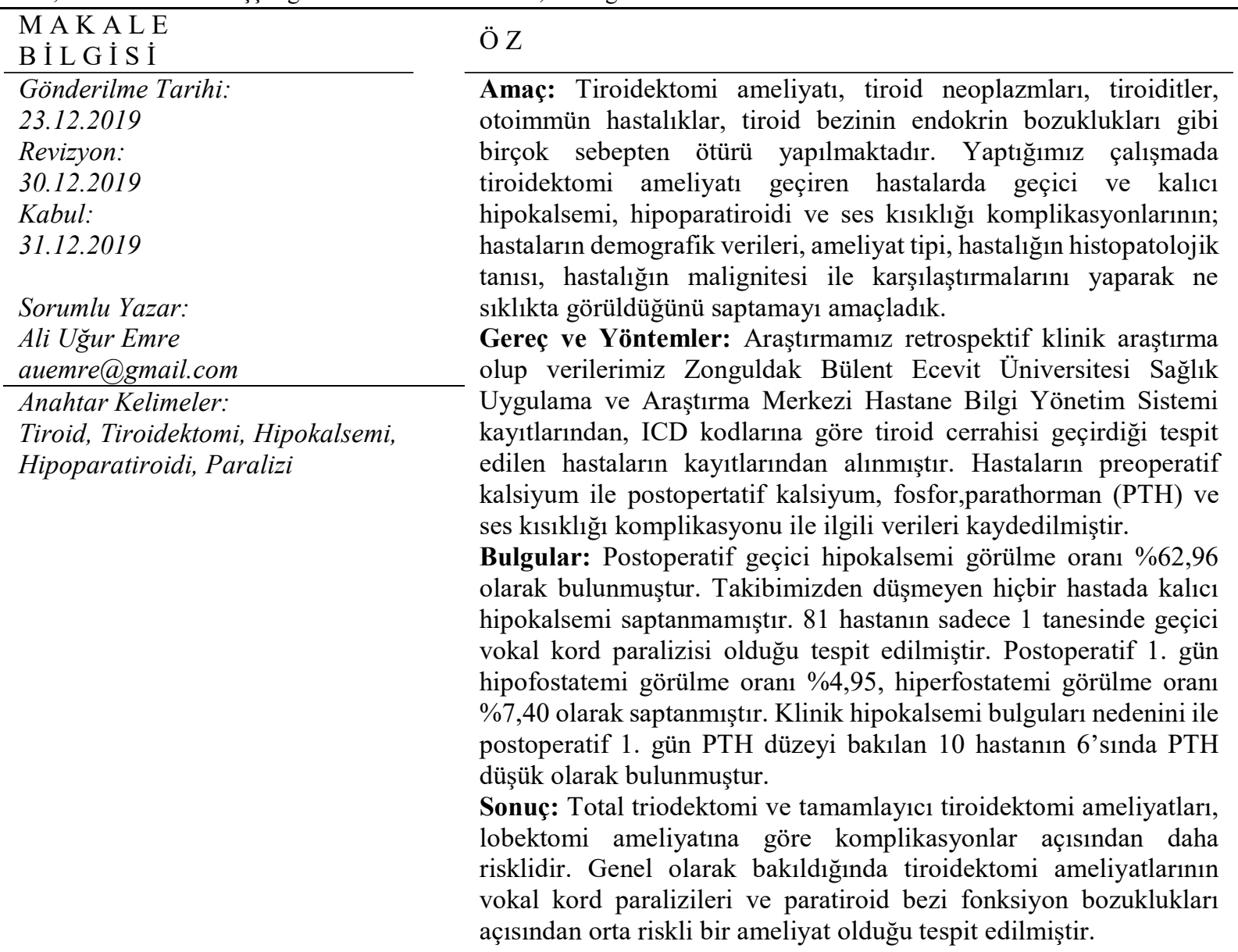

(C) 2019 Zonguldak Bülent Ecevit Üniversitesi Her hakkı saklıdır. 


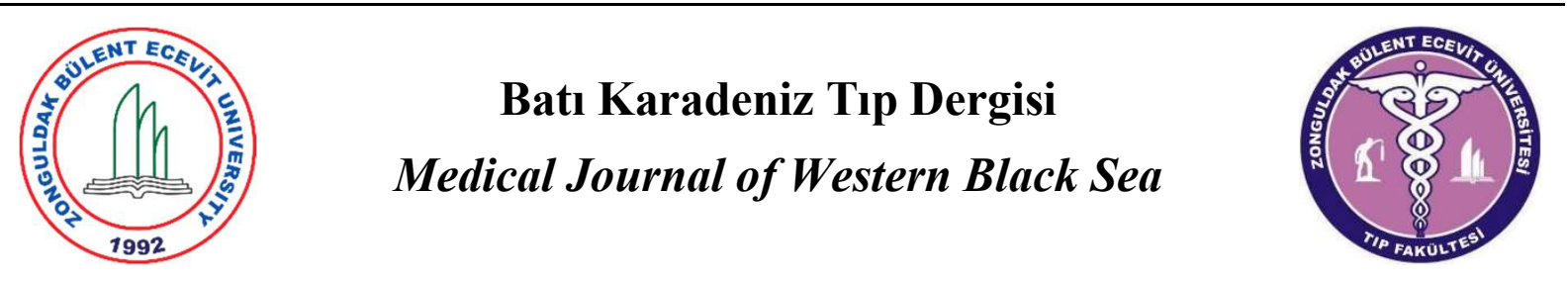

Research Article

Doi: $10.29058 /$ mjwbs.2019.3.1

\section{Retrospective Analysis of Transient and Permanent Hypocalcemia, Hypoparatyhroidism and Hoarseness After Thyroidectomy}

Onur Amaç a, Ömer Batuhan Öztürk a , Nurşah Uslu a , Osman Alperen Balık ${ }^{\text {a }}$, Nurhayat Karaca a, Ömer Tarık Çok ${ }^{\text {a }}$, Mustafa Sinan Kuşçuoğlu a , Ali Ŭgur Emre ${ }^{\text {b }}$

${ }^{a}$ Zonguldak Bulent Ecevit University School of Medicine Students, Zonguldak, Turkey.

${ }^{b}$ Zonguldak Bulent Ecevit University, School of Medicine, Department of General Surgery, Zonguldak, Turkey.

A R T I C L E

I N F O R M A T I O N

Date of Submission

23.12.2019

Revision:

30.12.2019

Accepted:

31.12.2019

Correspondence Author: Ali Uğur Emre

auemre@gmail.com

Key Words:

Thyroid, Thyroidectomy,

hypocalcemia,

hypoparathyroidism, paralysis

\section{A B S T R A C T}

Aim: Thyroidectomy is performed for many indications such as thyroid neoplasms, thyroiditis, autuimmune disorders and thyroid andocrine disorders. In this study we aimed to compare the incidence of transient and permanent hypocalcemia, hypoparathyroidism and hoarseness compications with the demographic features of the patients, type of surgery, histopathological diagnosis of the disease and presence of malignancy

Material and Methods: The data of the patients are obtained from the records of patients found to had a thyroidectomy procedure according to ICD codes from Zonguldak Bulent Ecevit University Hospital. Preoperative calcium and postoperative calcium, phosphorus, parathyroid hormone levels and the presence of postoperative hoarsness are noted.

Results: Postoperative transient hypocalcemia was present in $62,9 \%$ of patients. None of the patients had permanent hypocalcemia. Of 81 patients transient hoarsenes and vocal cord paralysis was observed in 1 patient. The rates of hypophosphatemia was $4.9 \%$, hyperphosphatemia was $7.4 \%$ in the first postoperative day. Of the 10 patients whose parathyroid hormone levels are obtained in the first posyoperative day due to clinical findings of hypocalcemia, 6 patients were found to have low Parathyroid hormone levels.

Conclusion: Total thyroidectomy and reoperative thyroidectomy is found to be more riskyin terms of complications. In general thyroidectomyis found to be a low risk surgery fort he risk of vocal cord paralysis. 


\section{Giriş}

Tiroid bezi en büyük endokrin organdır. Tiroid bezi hastalıkları günümüzde çok karşılaşılan sağlık problemlerinden biridir. Diabetes Mellitus'tan sonra 2. sıklıkta görülen endokrin hastalık olma özelliğini taşımaktadır.(1) Metabolizma üzerine olan etkisi dolayısıya kişinin günlük yaşamını yakından etkileyen hastalıklardan biridir. Tiroid bezi hastalıklarında medikal tedavinin yanı sıra cerrahi tedavi de çok sık tercih edilen bir tedavi yöntemidir. Tiroidektomi ameliyatı, tiroid neoplazmları, tiroiditler, otoimmün hastalıklar, tiroid bezinin diğer endokrin bozuklukları gibi birçok sebepten ötürü sık yapılan bir ameliyattır. Mortalitesi düşük olmasına karşın önemli morbiditelere neden olabilmektedir.(2) Anatomik yerleşimi ve komşuluğundaki önemli yapılar nedeni ile özel bir cerrahi gerektirmektedir.(3) Tiroid bezi ameliyatı sonrası çeşitli komplikasyonlar görülebilmektedir. Vokal kordları inerve eden rekürren laringeal sinirin tiroid bezine yakınlığı nedeni ile tiroidektomi ameliyatları sonrası bu sinirin paralizisi, dolayısıyla vokal kordların işlev görememesi gibi komplikasyonlar gelişebilmektedir.(2) S1k anatomik varsyosyonlar olması da komplikasyon oluşmasına neden olan bir diğer durumdur.(1) Ayrıca tiroid bezinin komşuluğunda bulunan 4 adet paratiroid bezi de bu ameliyatlar sırasında geçici veya kalıcı hasarlanabilmektedir.(4). Hastanelerin ve cerrahların vaka sayıları arttıkça ortaya çıkan komplikasyon oranları da düşmektedir. Yüksek hacimli cerrahi yapılan hastanelerde kar zarar oranları da daha iyidir (5)

Zonguldak Bülent Ecevit Üniversitesi Tıp Fakültesi Genel Cerrahi Anabilim Dalı'nda Ocak 2017-Ocak 2018 yılları arasında tiroid hastalıkları nedeniyle yapılan operasyonları, bu operasyonlar sonrası gelişen geçici ve kalıcı hipokalsemi, hipoparatiroidi, ses kısıklığı komplikasyonlarının ve bu komplikasyonlar ile hastaların demografik verileri, ameliyat tipi, hastalığın histopatolojik tanısı, hastalığın malignitesi arasındaki ilişkinin retrospektif araştırmasının yapılması amaçlanmıştır.

\section{Gereç ve Yöntemler}

Zonguldak Bülent Ecevit Üniversitesi Sağlık Uygulama ve Araştırma Merkezi Hastane Bilgi Yönetim Sistemi kayıtlarından Ocak 2017 - Ocak 2018 tarihleri arasında Genel Cerrahi Servisi'ne yatış yapmış ve tiroid ameliyatı geçirmiş hastalar ICD kodlarına göre taranarak hasta listeleri oluşturulmuştur. Tiroid hastalıkları nedeniyle hastaneye yatışı yapılan 129 hasta, tiroid cerrahisi geçirmiş 81 hasta saptanmıştır. $\mathrm{Bu}$ hastaların demografik özellikleri, geçirdiği ameliyat türleri, tiroidektomi materyallerinin patoloji sonuçları, ameliyat öncesi ve sonrası kalsiyum; ameliyat sonras1 fosfor, parathormon değerlerinin ve ses kısıklığı komplikasyonu olup olmadığının incelenmesi için Hastane Bilgi Yönetim Sistemi üzerinden ilgili hekimler nezaretinde hastaların patoloji raporu, preoperatif kalsiyum; postoperatif 1 . gün, 1. ay, 3. ay, 6. ay, 12. ay kalsiyum, parathormon ve fosfor değerlerinden ulaşılabilir sonuçlar kaydedilmiştir. Postoperatif 1. hafta, 1. ay, 3. ay, 6. ay, 12. ay ses kısıklığı nedeniyle Kulak Burun Boğaz konsultasyonu yapilan hastaların, konsultasyon raporlarının incelenip videostroboskopi ile kalıcı ve geçici vokal kord paralizisi olup olmadığı not edilmiştir. Hipokalsemi total serum kalsiyum düzeyinin $8,6 \mathrm{mg} / \mathrm{dl}$ altında olması, normal serum fosfor düzeyi 2.5-4.5 mg/dl, normal PTH serum düzeyi 15-65 pg/mL olarak tanımlanmıştır. Çalışmamız Zonguldak Bülent Ecevit Üniversitesi Klinik Araştırmalar Etik Kurulu 2019-36-14/02 protokol numaralı onayı ile yapılmıştır.

\section{Bulgular}

Tiroidektomi operasyonu geçiren hastaların 60'1 (\%74,1) kadın, 21'i $(25,9)$ erkektir. (Tablo 1) Operasyon geçiren hastalar arasında en genç hasta 23, en yaşlı hasta 78 yaşındadır. Yaş gruplarına göre kaç hasta bulunduğu ve yaş gruplarına göre yapılan operasyonların dağılımı Tablo 2'de gösterilmiştir. Buna göre hastaların en yoğun olduğu yaş 51-60 yaş arasında görülmekte $n=26(\% 32,1)$ ve yine bu yaş aralığında en fazla yapilan operasyonun total tiroidektomi olduğu $\mathrm{n}=20 \quad(\% 24,7) \quad$ tespit edilmektedir.

Total tiroidektomi 35 kadın 15 erkekte, lobektomi 20 kadın 4 erkekte, tamamlayıcı tiroidektomi ise 5 kadın 2 erkekte yapılmıştır (Tablo 3). 50 hastada total tiroidektomi $(\% 61,7), 24$ hastada tek taraflı tiroidektomi (Lobektomi) $(\% 29,6)$ ve 7 hastada tamamlayıcı tiroidektomi $(\% 8,7)$ yapılmıştır (Tablo 4). 
Tablo 1: Tiroidektomi cerrahisi geçiren hastaların yaşa göre cinsiyet dağılımı

\begin{tabular}{|llll|}
\hline & Kadin $\mathbf{n}(\%)$ & Erkek n (\%) & Toplam n (\%) \\
\hline $\mathbf{2 0 - 3 0}$ & $1(1,2)$ & $0(0)$ & $\mathbf{1}(\mathbf{1 , 2})$ \\
\hline $\mathbf{3 1 - 4 0}$ & $14(17,3)$ & $3(3,7)$ & $\mathbf{1 7}(\mathbf{2 1 , 0 )}$ \\
\hline $\mathbf{4 1 - 5 0}$ & $12(14,8)$ & $4(4,9)$ & $\mathbf{1 6}(\mathbf{1 9 , 7 )}$ \\
\hline $\mathbf{5 1 - 6 0}$ & $23(28,4)$ & $3(3,7)$ & $\mathbf{2 6}(\mathbf{3 2 , 1 )}$ \\
\hline $\mathbf{6 1 - 7 0}$ & $8(9,9)$ & $10(12,4)$ & $\mathbf{1 8 ( 2 2 , 3 )}$ \\
\hline $\mathbf{7 1 - 8 0}$ & $2(2,5)$ & $1(1,2)$ & $\mathbf{3 ( 3 , 7 )}$ \\
\hline Toplam & $\mathbf{6 0}(\mathbf{7 4 , 1 )}$ & $\mathbf{2 1}(\mathbf{2 5}, \mathbf{9})$ & $\mathbf{8 1}(\mathbf{1 0 0})$ \\
\hline
\end{tabular}

Tablo 2: Yapılan operasyonların yaşa göre dağılımı

\begin{tabular}{|c|c|c|c|c|}
\hline & $\begin{array}{l}\text { Total Tiroidektomi } \\
\text { n (\%) }\end{array}$ & $\begin{array}{l}\text { Lobektomi } \\
\text { n (\%) }\end{array}$ & $\begin{array}{l}\text { Tamamlayıcı } \\
\text { n (\%) }\end{array}$ & $\begin{array}{l}\text { Toplam } \\
\text { n (\%) }\end{array}$ \\
\hline 20-30 & $0(0)$ & $1(1,2)$ & $0(0)$ & $1(1,2)$ \\
\hline $31-40$ & $8(9,9)$ & $7(8,6)$ & $2(2,5)$ & $17(21,0)$ \\
\hline $41-50$ & $8(9,9)$ & $7(8,6)$ & $1(1,2)$ & $16(19,7)$ \\
\hline $51-60$ & $20(24,7)$ & $5(6,2)$ & $1(1,2)$ & $26(32,1)$ \\
\hline 61-70 & $11(13,6)$ & $5(6,2)$ & $2(2,5)$ & $18(22,3)$ \\
\hline $71-80$ & $2(2,5)$ & $0(0)$ & $1(1,2)$ & $3(3,7)$ \\
\hline
\end{tabular}

Tablo 3: Cinsiyete göre yapılan operasyonların dağılımı

\begin{tabular}{|lll|}
\hline & Kadın $\mathbf{n}(\%)$ & Erkek $\mathbf{n}(\%)$ \\
\hline Lotal Tiroidektomi & $35(58,4)$ & $15(71,4)$ \\
\hline Tamamlayı & $20(33,3)$ & $4(19,1)$ \\
\hline Toplam & $5(8,3)$ & $2(9,5)$ \\
\hline
\end{tabular}

Tablo 4: Yapılan operasyonların dağılımı

\begin{tabular}{|lll|}
\hline Total Tiroidektomi & $\mathbf{n}$ & $\%$ \\
\hline Tek Taraflı Tiroidektomi (Lobektomi) & 50 & $\% 61,7$ \\
\hline Tamamlayıcı Tiroidektomi & 24 & $\% 29,6$ \\
\hline Toplam & 7 & $\% 8,7$ \\
\hline
\end{tabular}

Opere edilen hastalarda 34 neoplastik lezyon, 47 non-neoplastik lezyon saptanmıştır. Neoplastik lezyonlar içinde malign ve benign lezyonlar eşit sayıda görülmektedir. Malignite saptanmış 17 hastanın, 16 tanesi Papiller Karsinom 1 tanesi ise Medüller Karsinom tanısına sahiptir. 16 Papiller Karsinom'un 10 tanesi Papiller Mikrokarsinom'dur. Malignite saptanmayan neoplastik lezyonlar ise 13 hastada Foliküler Adenom, 4 hastada Hurthle Hücreli Adenom şeklindedir. Non-neoplastik lezyonlarda ise en çok görülen lezyon Nodüler Hiperplazi'dir. 34 hastada görülmektedir. Ardından sirası ile 6 hastada Lenfositik Tiroidit, 4 hastada Lenfoid Hiperplazi, 2 hastada Hashimato Tiroiditi ve 1 hastada De Quervain Tiroiditi saptanmıştır (Tablo 5). Yapilan operasyonların neoplastik ve nonneoplastik hastalıklara göre göre dağılımı Tablo 6 ve Tablo 7'de verilmiştir. Buna göre; Papiller
Karsinom'u olan 14 hastada total tiroidektomi, 1 hastada lobektomi 1 hastada ise tamamlayıc tiroidektomi yapılmıştır. Medüller Karsinom tanısı almış hastada total tiroidektomi yapılmıştır. Foliküler adenom tanısı alan 6 hastada total tirodektomi, 7 hastada lobektemi yapılmıştır. Hurthle Hücreli Adenom'u olan hastaların 3 tanesine toral tiroidektomi, 1 tanesine lobektomi yapılmıştır. Nodüler Hiperplazi tanısı alan 18 hastaya total tiroidektomi, 10 hastaya lobektomi, 6 hastaya ise tamamlayıc1 tiroidektomi; Lenfoid Hiperplazi tanısı alan hastaların ise 1 tanesine total tiroidektomi, 3 tanesine lobektomi yapılmıştır. Lenfositik Tiroidit tanıs1 alan 5, Hashimato Tiroiditi tanıs1 alan 2 hastaya total tiroidektomi; Lenfositik Tiroidit ve De Qurvan Tiroiditi tanısı alan 1'er hastaya lobektomi yapılmıştır. 
Tablo 5: Tiroidektomi materyallerinin histopatolojik tanılarına göre dağılımı

\begin{tabular}{|cll|}
\hline Neoplastik Lezyonlar & $\mathbf{n}$ & $\mathbf{\%}$ \\
\hline Malign Lezyonlar & $\mathbf{3 4}$ & $\mathbf{4 2 , 0}$ \\
\hline Papiller Karsinom & $\mathbf{1 7}$ & $\mathbf{2 1 , 0}$ \\
\hline Medüller Karsinom & 16 & 19,8 \\
\hline Benign Lezyonlar & 1 & 1,2 \\
\hline Foliküler Adenom & $\mathbf{1 7}$ & $\mathbf{2 1 , 0}$ \\
\hline Hurthle Hücreli Adenom & 13 & 16,1 \\
\hline & 4 & 4,9 \\
\hline Non-neoplastik Lezyonlar & $\mathbf{4 7}$ & $\mathbf{5 8 , 0}$ \\
\hline Nodüler Hiperplazi & 34 & 42,0 \\
\hline Lenfoid Hiperplazi & 4 & 4,9 \\
\hline Lenfositik Tiroidit & 6 & 7,4 \\
\hline Hashimato Tiroiditi & 2 & 2,5 \\
\hline De Quervain Tiroiditi & 1 & 1,2 \\
\hline & & $\mathbf{0 1 0 0}$ \\
\hline Toplam & $\mathbf{8 1}$ & \\
\hline
\end{tabular}

Tablo 6: Yapılan operasyonların neoplastik lezyonlara göre dağılımı

\begin{tabular}{|c|c|c|c|}
\hline & $\begin{array}{l}\text { Total Tiroidektomi } \\
\text { n }(\%)\end{array}$ & $\begin{array}{l}\text { Lobektomi } \\
\text { n }(\%)\end{array}$ & $\begin{array}{l}\text { Tamamlayıcı } \\
\text { n }(\%)\end{array}$ \\
\hline Malign Lezyonlar $(n=17)$ & $15(88,2)$ & $1(5,9)$ & $1(5,9)$ \\
\hline Papiller Karsinom & $14(82,3)$ & $1(5,9)$ & $1(5,9)$ \\
\hline Medüller Karsinom & $1(5,9)$ & $0(0)$ & $0(0)$ \\
\hline Benign Lezyonlar $(n=17)$ & $9(52,9)$ & $8(47,1)$ & $0(0)$ \\
\hline Foliküler Adenom & $6(35,3)$ & $7(41,2)$ & $0(0)$ \\
\hline Hurthle Hücreli Adenom & $3(17,6)$ & $1(5,9)$ & $0(0)$ \\
\hline
\end{tabular}

Tablo 7: Yapılan operasyonların non-neoplastik lezyonlara göre dağılımı

\begin{tabular}{|c|c|c|c|}
\hline & $\begin{array}{l}\text { Total } \\
\text { Tiroidektomi } \\
\text { n (\%) }\end{array}$ & $\begin{array}{l}\text { Lobektomi } \\
\text { n (\%) }\end{array}$ & $\begin{array}{l}\text { Tamamlayıcı } \\
\text { n }(\%)\end{array}$ \\
\hline Hiperplazi Tanımlanan Hastalar (n:38) & $19(50,0)$ & $13(34,2)$ & $6(15,8)$ \\
\hline Nodüler Hiperplazi & $18(47,4)$ & $10(26,3)$ & $6(15,8)$ \\
\hline Lenfoid Hiperplazi & $1(2,6)$ & $3(7,9)$ & $0(0)$ \\
\hline Tiroidit Tanımlanan Hastalar (n:9) & $7(77,8)$ & $2(22,2)$ & $0(\mathbf{0})$ \\
\hline Lenfositik Tiroidit & $5(55,6)$ & $1(11,1)$ & $0(0)$ \\
\hline Hashimato Tiroiditi & $2(22,2)$ & $0(0)$ & $0(0)$ \\
\hline De Quervain Tiroiditi & $0(0)$ & $1(11,1)$ & $0(0)$ \\
\hline
\end{tabular}

Malignite tanısı alanı 17 hastanın 12 tanesi 41-60 yaş arasında arasında olup, bu hastalar malign tanıya sahip tüm hastaların \%70,6'sını oluşturmaktadır (Tablo 8). Opere edilen hastalarda postoperatif 1. gün, 61 hastada hipokalsemi saptanmıştır. (Tablo 9) Kadınlarda postoperatif 1. Gün hipokalsemi görülme oranı $\% 80$, erkeklerde $\% 61,9$ 'dur. $\mathrm{Bu}$ oran tüm hastalarda \%75,3'tür. Postoperatif 1. gün hipokalsemi görülen 5 erkek hastada ileriki kontrollerinde düzelme görülürken. 8 erkek hasta takipten düşmüştür. 29 kadın hastada ileriki kontrollerinde düzelme görülürken 19 kadın hasta takipten düşmüştür. Takibimizden düşmeyen hastalar değerlendirildiğinde postoperatif geçici hipokalsemi görülme oranı \%63'tür. 1 hastada preoperatif hipokalsemi mevcuttur Hastada postoperatif hipokalsemi de görülmektedir. Ardından hasta takipten düşmüştür. 1 hastada da 
preoperatif hiperkalsemi mevcut olup ameliyat sonrası hipokalsemik olan hasta ileriki takiplerinde normal kan kalsiyumu seviyesine ulaşmıştır. Postoperatif 1 . ay ve 6 . ay 3 hastada hiperkalsemi mevcut olup 2 hasta tekrar normal kan kalsiyumu seviyelerine ulaşmış 1 hasta takipten düşmüştür Postoperatif 1. Gün hipokalsemi en çok 51-60 yaş grubunda görülmektedir. Bu tüm hastaların yaklaşık 4'te 1'i kadardır ve oranı \%25,9'dur (Tablo 10). Total tiroidektomi ve tamamlayıc1 tiroidektomi operasyonları sonrası hastalarda postoperatif 1. gün hipokalsemi görülme oranı sirasıyla $\% 80$ ve 85,7'yken Lobektomi ameliyatları sonras1 postoperatif 1. gün hipokalsemi görülme oranı \%62,5'tir (Tablo 11). Neoplastik lezyonlarda postoperatif 1. gün hipokalsemi görülme oranı 70,6'yken non-neoplastik lezyonlarda oran \%83'tür (Tablo 12). Neoplastik lezyonlarda malign tanıya sahip hastalarda ve benign tanıya sahip hastalarda postoperatif 1. gün hipokalsemi görülme oranı eşit ve $\% 70,6$ dir (Tablo 13). Tiroidektomi operasyonu geçiren 6 hastada postoperatif 1 . gün hiperfosfatemi,
4 hastada postoperatif 1. gün hipofosfatemi görülmüştür. 71 hastada ise postoperatif 1. gün fosfor değeri normal seviyede izlenmiştir (Tablo 14). Hipofosfatemi saptanan 2 hastanın fosfor değeri 1. ay ve 6. ay normal aralıkta saptanırken diğer iki hasta takipten düşmüştür. Hiperfosfatemi saptanan 2 hastada 1. ay, 1 hastada 12. ay normal fosfor değeri ölçülmüştür. 1 hasta postoperatif 1. gün fosfor ölçüldükten sonra takipten düşmüştür. 1 hasta ise 1 . Ay ve 3. Ay hiperfosfatemisi devam etmiş ve daha sonrasında takipten düşmüştür. Tiroidektomi opersyonu geçiren hastaların ulaşılabilir verileri değerlendirildiğinde postoperatif (PO) 1. gün Parathormon (PTH) düzeyi 1 hastada yüksek, 3 hastada normal, 6 hastada düşük saptanmıştır (Tablo 15). Opere edilen hastaların 2 tanesinde ses kısıklı̆̆ raporlanmıştır. $\mathrm{Bu}$ hastaların birinde PO 1. Hafta raporlanan ses kısıklığının 6 ay itibariyle düzelmiş olduğu belirtilmiştir. Diğer hasta da ise PO 1. Ay ses kısıklığı raporlanmış ardından hasta takipten düşmüştür. Araştırmamızda geçici ses kısıklığ komplikasyonu oranı \%1,23 olarak bulunmuştur.

Tablo 8: Malignite tanısı alan hastaların yaş gruplarına göre dağılımı

\begin{tabular}{|lll|}
\hline $\mathbf{2 0 - 3 0}$ & n & $\%$ \\
\hline $\mathbf{3 1 - 4 0}$ & 0 & 0 \\
\hline $\mathbf{4 1 - 5 0}$ & 4 & 23,5 \\
\hline $\mathbf{5 1 - 6 0}$ & 6 & 35,3 \\
\hline $\mathbf{6 1 - 7 0}$ & 6 & 35,3 \\
\hline $\mathbf{7 1 - 8 0}$ & 1 & 5,9 \\
\hline Toplam & 0 & 0 \\
\hline
\end{tabular}

Tablo 9: Cinsiyete göre postoperatif 1. gün hipokalsemi görülme oranı

\begin{tabular}{|c|c|c|}
\hline & Postoperatif 1. Gün Hipokalsemi n (\%) & Normal n (\%) \\
\hline $\operatorname{Kadın}(n=60)$ & $48(80,0)$ & $12(20,0)$ \\
\hline Erkek $(n=21)$ & $13(61,9)$ & $8(38,1)$ \\
\hline Toplam & $61(75.3)$ & $20(24,7)$ \\
\hline
\end{tabular}

Tablo 10: Yaşa göre postoperatif 1. gün hipokalsemi görülme oranı

\begin{tabular}{|lll|}
\hline $\mathbf{2 0 - 3 0}$ & Postoperatif 1. Gün Hipokalsemi n $(\%)$ & Normal n $(\mathbf{\%})$ \\
\hline $\mathbf{3 1 - 4 0}$ & $0(0)$ & $1(1,2)$ \\
\hline $\mathbf{4 1 - 5 0}$ & $12(14,8)$ & $5(6,2)$ \\
\hline $\mathbf{5 1 - 6 0}$ & $12(14,8)$ & $4(4,9)$ \\
\hline $\mathbf{6 1 - 7 0}$ & $21(25,9)$ & $5(6,2)$ \\
\hline $\mathbf{7 1 - 8 0}$ & $13(16,1)$ & $5(6,2)$ \\
\hline Toplam & $3(3,7)$ & $0(0)$ \\
\hline
\end{tabular}

Tablo 11: Yapılan operasyon türüne göre postoperatif 1. gün hipokalsemi görülme oranı

\begin{tabular}{|llll|} 
& $\begin{array}{l}\text { Postoperatif 1. Gün Hipokalsemi } \\
\text { n (\%) }\end{array}$ & $\begin{array}{l}\text { Normal } \\
\text { n (\%) }\end{array}$ & $\begin{array}{l}\text { Toplam } \\
\text { n }(\%)\end{array}$ \\
\hline Total Tiroidektomi & $40(80,0)$ & $10(20,0)$ & $\mathbf{5 0 ( 1 0 0 )}$ \\
\hline Lobektomi & $15(62,5)$ & $9(37,5)$ & $\mathbf{2 4}(\mathbf{1 0 0})$ \\
\hline Tamamlayıcı Tiroidektomi & $6(85,7)$ & $1(14,3)$ & $\mathbf{7 ( 1 0 0 )}$ \\
\hline
\end{tabular}


Tablo 12: Postoperatif 1. gün hipokalsemi görülme oranının neoplastik ve non-neoplastik lezyonlara göre dağılımı

\begin{tabular}{|llll|} 
& $\begin{array}{l}\text { Postoperatif 1. Gün Hipokalsemi } \\
\text { n (\%) }\end{array}$ & $\begin{array}{l}\text { Normal } \\
\text { n (\%) }\end{array}$ & $\begin{array}{l}\text { Toplam } \\
\text { n }(\%)\end{array}$ \\
\hline Neoplastik Lezyonlar & $24(70,6)$ & $10(29,4)$ & $\mathbf{3 4}(\mathbf{1 0 0})$ \\
\hline Non-neoplastik Lezyonlar & $39(83,0)$ & $8(17,0)$ & $\mathbf{4 7}(\mathbf{1 0 0})$ \\
\hline
\end{tabular}

Tablo 13: Postoperatif 1. gün hipokalsemi görülme oranının malign ve benign lezyonlara göre dağılımı

\begin{tabular}{|llll|} 
& $\begin{array}{l}\text { Postoperatif 1. Gün Hipokalsemi } \\
\text { n }(\%)\end{array}$ & $\begin{array}{l}\text { Normal } \\
\text { n (\%) }\end{array}$ & $\begin{array}{l}\text { Toplam } \\
\text { n }(\%)\end{array}$ \\
\hline Malign Lezyonlar & $12(70,6)$ & $5(29,4)$ & $\mathbf{1 7}(\mathbf{1 0 0})$ \\
\hline Benign Lezyonlar & $12(70,6)$ & $5(29,4)$ & $\mathbf{1 7}(\mathbf{1 0 0})$ \\
\hline
\end{tabular}

Tablo 14: Tiroidektomi cerrahisi geçiren hastalarda postoperatif 1. gün fosfor düzeylerinin dağılımı

\begin{tabular}{|lll|}
\hline Yüksek & n & $\%$ \\
\hline Normal & 6 & 7,4 \\
\hline Düşük & 71 & 87,7 \\
\hline
\end{tabular}

Tablo 15: Tiroidektomi cerrahisi geçiren hastalarda postoperatif 1. gün PTH düzeylerinin dağılımı

\begin{tabular}{llll|} 
& Yüksek n (\%) & Normal n (\%) & Düşük n (\%) \\
\hline
\end{tabular}

\section{Tartışma}

Yaptığımız araştırmamı sonucunda tiroid hastalıklarının kadın/erkek görülme oranının yaklaşık olarak 3/1 olduğunu saptatık. 61 kadın, 20 erkek hastanın tiroid cerrahisi geçirdiğini belirledik. $\mathrm{Bu}$ verimiz literatürde yazan tiroid hastalıkları kadınlarda daha sık görülür bilgisi ile uyumludur.(6)

En genç hastamız 23, en yaşlı hastamız 78 yaşındaydı. Ama hastaların en çok bulunduğu yaş grubunun sırasıyla 51-60 ve 61-70 yaş grupları olduğunu saptadık. Bu iki gruptaki hasta sayısı hastaların yarısından fazlaydı.

Yapılan ameliyatların sıklığının sırası ile total tiroidektomi, tek taraflı total tiroidektomi (Lobektomi) ve tamamlayı tiroidektomi olduğunu saptadık. Hiçbir hastada subtotal tiroidektomi yapılmamıştır. Subtotal tiroidektomi yapılmamasının nedeninin komplikasyonlar açısından daha riskli bir ameliyat olduğunu düşünüyoruz.(7)

Opere edilen hastalarda non-neoplastik lezyonların, neoplastik lezyonlardan daha sik görüldüğünü saptadık. Non-neoplastik lezyonlar arasında en sik görülen Nodüler hiperlazidir. Neoplastik lezyonlarda ise malign ve benign lezyonların eşit sayıda görüldüğünü saptadık. En sık görülen malign lezyon papiller karsinom, en sık görülen benign lezyon ise foliküler adenomdur. Malign tanıya sahip hastaların belirlediğimiz yaş gruplarında en sık 41-60 yaş arasında görüldüğünü saptadık. Bu yaş aralığındaki hastalar tüm hastaların \% 70,6'sina denk gelmektedir.

Opere edilen hastalardan 61 tanesinin PO 1. gün kalsiyum seviyeleri düşüktür. PO 1. gün hipokalsemi görülme oranı kadınlarda \%80 iken erkeklerde bu oran daha düşüktür. Takibimizden düşmeyen hastalar değerlendirildiğinde geçici hipokalsemi görülme oranını $\% 63$ olarak saptadık. Bunun literatürdeki oranlardan fazla olduğunun tespit ettik.(8)(9)(10) Hastaların büyük bir çoğunluğunda PO hipokalsemi 1. günden sonra hızla düzelmiştir. Elde ettiğimiz bu veri tiroid cerrahisi geçiren hastalarda erken (PO 1. gün) kalsiyum replasmanının tartışılmasının uygun olduğunu düşündürmüştür.

PO 1. gün hipokalsemi görülme oranının total tiroidektomi ve tamalayıcı tiroidektomide yüksek, lobektomi ameliyatında ise daha düşük olduğunu saptadık. Lobektomi ameliyatlarında PO 1. gün hipokalsemi komplikasyonun daha az görülme nedeninin cerrahisinin diğer iki paratiroid bezi ile ilişkili olmaması, olduğunu düşünüyoruz.

Non-neoplastik lezyonlarda görülen PO 1. gün hipokalseminin neoplastik lezyonlardan daha yüksek oranda olduğunu ve neoplastik lezyonlar 
arasında malign ve bening lezyonlarda görülen PO 1. gün hipokalseminin eşit olduğunu saptadık. PO 1. gün hipokalsemi komplikasyonunun görülme sıklığı ile lezyonun türü ve malignitesi arasındaki ilişkinin ameliyat türü ile olan ilişkisinden daha düşük olduğunu düşünüyoruz. PO 1. gün fosfor seviyelerin hastaların büyük bölümünde normal olduğunu saptad1k.

Hipoparatiroidi komplikasyonu açısından çok anlamlı verilere ulaşamasak da operasyon sonrası klinik hipokalsemi bulguları nedeni ile PTH düzeyi bakılan hastaların çoğunda PTH değerlerinin düşük olduğunu saptadık.

Yapılan operasyonlar sonucu 1 hastada geçici vokal kord paralizisi olduğunu saptadık. Bunun literatürdeki veriler ile uyumlu olduğunu tespit ettik.(2)(11) 1 hastayı ise takibimizden düştüğü için değerlendiremedik.

Retrospektif bir çalışma yapmamız nedeni ile hastaların tüm verilerine ulaşamadık. Takibimizden düşen hastaları değerlendiremedik.

Bu çalışma IV. Zonguldak Endokrin Günleri, Ulusal Endokrin Hastalıklara Multidisipliner Güncel Yaklaşım Kongresinde sözlü bildiri olarak sunulmuştur.

\section{Kaynaklar}

1. Bozdağ, A. D., Çevikel, M. H., Demirkıran, A. E., Erpek, H., Boylu, Ş., \& Özgün, H.Benign tiroid cerrahisinde postoperatif komplikasyonları etkileyen risk faktörleri. ADÜ Tıp Fakültesi Dergisi 2002; 3(3) : $25-29$

2. Mutlu, A. T., Berkiten, G., Kumral, T. L., \& Uyar, Y. Tiroid Cerrahisinin Laringeal Komplikasyonları. Okmeydanı Tıp Dergisi,2012; 15(3): 5-8.

3. Toprak, D., Doğanay, M., \& Kama, N. A. Tiroid operasyonlarından sonra görülen komplikasyonlar. Kocatepe Tıp Dergisi,2004; 5(1):1-6

4. Christou, N., and M. Mathonnet. "Complications after total thyroidectomy." Journal of visceral surgery, 2013:150.(4); 249-256.

5. Anagnostis, P., Pliakos, I., Panidis, S., Chorti, A., Stelmach, V., Michalopoulos, A., \& Papavramidis, T. S. Should total thyroidectomies be performed by high-volume endocrine surgeons? A costeffectiveness analysis. Endocrine, 1-5.
6. Reiners, Christoph, et al. "Prevalence of thyroid disorders in the working population of Germany: ultrasonography screening in 96,278 unselected employees." Thyroid, 2004; 11(14): 926-932.

7. Çağlayan, K., \& Çelik, A. Benign tiroid hastalığında ameliyat yöntemleri ve komplikasyonların incelenmesi: Tiroidektomi ve komplikasyonları. Turkish Journal of Surgery/Ulusal Cerrahi Dergisi, 2010:26(3).

8. Asari, Reza, et al. "Hypoparathyroidism after total thyroidectomy: a prospective study." Archives of Surgery 2008: 143.(2); 132-137.

9. Uludağ, M., Besler, E., Aygün, N., Çitgez, B., Mihmanlı, M., Yetkin, S. G., \& İşgör, A. Tiroid cerrahisi sonrası hipokalsemi gelişimini etkileyen faktörler. Şişli Etfal Tıp Bülteni, 2015:49(2); 101106.

10. Cinel, A., Türkyılmaz, S., Alhan, E., Gamze, Ç. A. N., Akçay, M., \& Özkul, F. Total Tiroidektomi Yapılan Hastalarda Post Operatif Komplikasyonların Yaş Gruplarına Göre Karşılaştırılması. Düzce Tıp Fakültesi Dergisi, 2013:15(3); 5-8.

11. Schneider, R. "Postoperative vocal fold palsy in patients undergoing thyroid surgery with continuous or intermittent nerve monitoring." British Journal of Surgery2015: 102.(11); 1380-1387. 
